\title{
Production Control and Corporate Productivity Performance in the Nigerian Manufacturing Industry
}

\author{
${ }^{1}$ G.I. Umoh, ${ }^{2}$ Ify Harcourt Wokocha, \\ ${ }^{I}$ Management Department, Faculty of Management Sciences, University of Port Harcourt, Port Harcourt. \\ Nigeria. \\ ${ }^{2}$ Office Technology and Management, School of Management Sciences, Rivers State College of Arts and \\ Sciences, Rumuola Port Harcourt
}

\begin{abstract}
This paper investigates the extent to which Production Control, had affected the Corporate Productivity Performance of the Nigerian manufacturing industry. Three hypotheses were formulated and questionnaire were distributed to eighty respondents in the eighty sampled manufacturing firms from the one hundred in the industry, quoted in the Stock Exchange(Fact Book 2009). Sixty two copies of the questionnaire were retrieved. These with the financial statements of the firms were used for the analysis. From its findings, the study revealed that production control has significant impacts on Corporate Productivity Performance of Nigerian manufacturing industry. This finding implies that production control significantly affects the Corporate Productivity Performance of firms. Based on these, the study recommends among others, that the Nigerian manufacturing industry should efficiently and effectively operationalize an all embracing production control, in order to restore the industry as the base of all development.
\end{abstract}

Keywords: Production Control, Corporate Productivity Performance.

\section{Introduction}

In the evolutionary thesis of man, production has been the major function directed at creating value and therefore growing wealth in society (Bestwick and Lockyer, 2008; and Mundel, 1983; ). The historical discourse of Production Control $(\boldsymbol{P C})$ therefore revolves around Corporate Productivity Performance $(\boldsymbol{C P P})$. This argument supports the assertion that there is a link between $\boldsymbol{P C}$ and $\boldsymbol{C P P}$. This is because, $\boldsymbol{C P P}$ has been of central importance to managers and researchers in all forms of formal business organisations, and it is acknowledged to be a crucial factor in organisational efficiency and effectiveness ( Billington et al, 2003; and Pineda, 2009). To this end, Brayton (1983) and Buffa (2001) argue that for business organisations to contribute to economic growth in society, they must ensure commitment in the exercise of $\boldsymbol{P C}$ and be passionate about its impacts on $\boldsymbol{C P P}$ which is measured with cost minimization, enhanced equity capital and growth dimensions. This lends support to Graig and Harris (1973) assertion that PC, which is the design and use of a systematic procedure for establishing plans and controlling all the elements of activities in the plan to meet its requirements, has continued to be a topical issue in production management and operations research, and will continue to engage the attention of scholars and practitioners in the future.

In the wake of 2008 , the world experienced a depression which settled for the global economic meltdown. Eleanya(2009) stated that the European, American and Asian States did not just relax and watch the meltdown wreck the economy. He explained that even in West Africa, a country like Ghana with her very limited resources did not relax in the face of the meltdown. Every little effort put forward by these countries to revamp their manufacturing sectors yielded fantastic result, either by the public, private or both sectors. The reverse is the case in Nigeria, where huge amount of the peoples' resources have been pumped into the manufacturing sector and no visible result is recorded. Instead the sector is seriously declining.

Jain and Aggarwal (2008) state that, every manufacturing activity requires resource input in terms of men, materials, money and machines. They went further to state that in any business that produces a product or service production activity must be related to market demands as indicated by the continuous stream of customers' orders. It follows therefore that for maximum effectiveness, this must be done in such a way that customers' demands are satisfied, but at the same time production activities are carried on in an economic manner. They went further to explain that one of the processes of developing this kind of relationship between market demands and production capability is the function of production control $(\boldsymbol{P C})$ which has been described as the design and use of a systematic procedure for establishing predetermined manufacturing requirements of such things as available basic materials, detailed equipments, production runs, order priority, money, man and production process within the scope of the enterprise for efficient production of goods to match its sale requirements and controlling all these elements of activities in the plan to meet the requirements of the organisation. 
$\boldsymbol{P C}$ can be effected principally through the management of workflow, inventories and backlogs, and changing levels of operation (Winston, 2004; Hillier and Lieberman, 2005; Jain and Aggarwal, 2008). Buffa (1975) had maintained that this tool is indispensable in any firm irrespective of size and complexity. It is with the understanding and application of this basic tool that advanced countries had contained the global economic crisis that would have ravaged their economies.

Production is a process or procedure developed to transform a set of inputs like men, materials, capital, information and energy into a specified set of output like finished products and services in proper quantity and quality, thus achieving the objectives of an enterprise' (Vollman et al, 2007; and Jain and Aggarwal, 2008). The production system likewise is the design process by which elements are transformed into useful products. A process then is an organized procedure for accomplishing the conversion of inputs into output. Production is effective if an appropriate and efficient $\boldsymbol{P C}$ technique is in place.

It is the understanding, design and application of this technique that form the focal concept of this research in the Nigerian state. If the manufacturing sector of the Nigerian economy is seriously declining in its contribution to $\boldsymbol{G D P}$, then there is probably the problem of understanding, design and application of $\boldsymbol{P C}$ in the Nigerian economy-especially in the real sector where manufacturing is predominant. This research has looked at existing models and techniques (linear programming, piecewise linear production and quadratic cost models for example) to find out if they are applied anywhere in the industries under study. The study also sought to establish how suitable such models must have been in the context of the Nigerian economy. It is argued that the existing models could not have been developed with the Nigerian economy in mind, or that our economy lacked proper understanding of such models, thereby being unable to adapt it for application in the Nigerian economy.

Despite the rich natural, human and capital resources in the environment, the Nigerian manufacturing sector and indeed the economy is recording a high level of de-industrialization (Eke, 1985; Eleanya, 2002, 2009; Green, 2006). Eleanya(2009) went on to say that this situation seems to sow the seed for more violent political and social instability. This, he stated is because the level of unemployed but employable citizens had continued to: (1) increase exponentially; (2) create a large reserve army of recruitable political thugs and gangsters capable of short-changing citizens electorally; (3) generate large number of militants, armed robbers, kidnappers and criminals who will make life nasty, short and brutish for citizens; (4) help to accelerate state failure; and (5) embark on the revolutionary reorganization and reordering of society. If other economies of Europe, America and Asia have developed a robust $\boldsymbol{P C}$ mechanisms that could enhance business organisational goals- like corporate productivity performance $(\boldsymbol{C P P})$ of cost minimization, profit maximization, enhanced equity capital and growth, then there is no excuse whatsoever that Nigeria can give for not accomplishing same with her existing human and economic resources (Jain and Aggarwal, 2008).

We have earlier explained that $\boldsymbol{P C}$ entails the establishment and control of the process of managing workflow, inventories and backlogs, and changing levels of operations to accelerate productivity so that goods and services may find a suitable market (Winston, 2004; Winston and Albright, 2007; Jain and Aggarwal, 2008). Accordingly, the highest efficiency in production is obtained by manufacturing the required quantity of product, of the required quality, at the required time by the best of cheapest method (Bestwick and Lockyer, 2008; Johnson and Montgomery 2009; Wild, 2008; Lockyer, 2009). To attain this objective, management employs $\boldsymbol{P C}$ as a tool to coordinate and enhance the performance of all manufacturing activities.

Research evidence has shown in Eleanya(2009) that in Singapore, South Korea, Indonesia, Thailand and Malaysia the manufacturing sector contribution to Gross Domestic Product (GDP) is well over sixty percent $(60 \%)$. These are countries that have through massive industrialization joined the class of world industrialized nations. Indeed, China whose independence is about eleven (11) years older than Nigeria, has manufacturing share of $\boldsymbol{G D P}$ as high as eighty percent (80\%). As at today manufacturing sector's contribution to $\boldsymbol{G D P}$ in Nigeria is less than three percent (3\%). This is a problem.

There is therefore the need to collectively sustain the pressure and advocacy for friendly business environment, stable macro-economic policies, consistent, clear and focused industrial strategy that will provide support and incentive for manufacturing activities, ensure value addition and job creation, to give the economy the required organizational productivity of profit maximization/cost minimization, and development in general.

Thinking along the reasoning of Fowge (1997), it is our belief that interest in $\boldsymbol{P C}$ and corporate productivity performance has spurred curiosity beyond the capacity of scholars to keep pace with it either theoretically or methodologically. This seems to us to be the case in Nigeria as we do not find sufficient evidence of empirical studies on $\boldsymbol{P C}$ and its impact on $\boldsymbol{C P P}$ in the Nigerian Manufacturing Industry. Correspondingly empirical studies on $\boldsymbol{P C}$ and $\boldsymbol{C P P}$ specific-research in Nigeria are scanty (Chinweizu, 1979; Agbadudu, 1996) although Chase et al (2001) while acknowledging that the models of $\boldsymbol{P} \boldsymbol{C}$ and $\boldsymbol{C P P}$ have been developed and tested in western countries, advocates that there is a need for more systematic research to determine whether these models apply elsewhere. It is upon this premise that this study sets out to examine the impact of $\boldsymbol{P C}$ on $\boldsymbol{C P P}$ in the Nigerian Manufacturing Industry with a view to enhancing organizational effectiveness and competitive advantage. 


\section{Theoretical Foundation.}

Two key variables formed the focus of this study and they were the Criterion Variable - $\boldsymbol{C P P}$ which depends on the Predictor Variable $-\boldsymbol{P C}$. We defined $\boldsymbol{C P P}$ as measured by cost minimization, enhanced equity capital and growth. It was assumed that the practices of $\boldsymbol{P C}$ will trigger $\boldsymbol{C P P}$ through its dimensional effects on cost minimization, enhanced equity capital and growth.

The objectives and the research questions for the study were drawn from the hypothesized relationships between the predictor and criterion variables. The framework assumes a straight line relationship between the predictor variable and the criterion variables. The conceptual framework, which is unidirectional, indicates that $\boldsymbol{C P P}$ is a function of $\boldsymbol{P C}$. This is represented in the following mathematical model:

$$
\begin{aligned}
\boldsymbol{C P P}=f(\boldsymbol{P C}) & \\
\text { Where: } & \\
& \boldsymbol{C P P}=\text { Corporate Productivity Performance. } \\
& \boldsymbol{P C}=\text { Production Control }
\end{aligned}
$$

From the conceptual framework, $\boldsymbol{C P P}$ is measured by the level of cost minimization, enhanced equity capital and growth. The framework also shows the dimension of $\boldsymbol{P C}$ as production control. Consequently our mathematical model can be expanded thus:

$$
\begin{aligned}
\boldsymbol{C P P}=f(\mathrm{c}) & \\
\text { Where: } & \\
& \mathrm{c}=\text { control }
\end{aligned}
$$

\section{Methodology.}

The cross sectional survey design is considered most appropriate because what is being investigated is experiences (Anwuluorah, 1987). Again the range of issues and inter-relations are numerous and diverse. The study is also a causal study that is intended to identify the effect of the application of $\boldsymbol{P C}$ on $\boldsymbol{C P P}$ in the manufacturing industry. The design is expected to reveal the relationship between $\boldsymbol{P C}$ and $\boldsymbol{C P P}$. The purpose of a cross-sectional survey therefore is to generate a body of data in connection with two or more variables, and to examine and identify patterns of association (Nachimias, and Nachimias, 2009). This design meets our purpose and enables us to generalize from the result of our sample for the entire population. Furthermore, the causal investigation is adopted in this study and is built around the purpose of hypothesis testing in which we examined the causal relationship between $\boldsymbol{P C}$ and $\boldsymbol{C P P}$ in a non-contrived setting.

\subsection{Population of the Study}

The population consists of those manufacturing companies quoted in the Nigerian Stock Exchange (NSE) fact book of 2009. A total of one hundred (100) manufacturing companies were identified, but a sample of eighty $(80)$ was drawn for the study using stratified random sampling method. In this case, the proportional allocation approach was used firstly to determine the number of companies in each stratum (sector) as classified by the Nigerian Stock Exchange (NSE) Factbook of 2009. Thereafter a simple random sampling technique was used to select members of the sample from each stratum (sector).

\subsection{Data Collection Methods}

Primary and secondary sources of data collection were explored for this study. The primary data were gathered through the administration of questionnaire designed using Five-Point Likert-Scale. While the secondary data were sourced from the companys' financial statements as reported in the Nigerian Stock Exchange Factbook of 2009.

The structured questionnaire containing questions relating to $\boldsymbol{P C}$ with dimension such as production control, as it affects $\boldsymbol{C P P}$ of firms in the Nigerian manufacturing industry were served on chief executives or senior managers in the production and operations department. The copies of the questionnaire were administered personally and online (where applicable) by the researcher to the respondents. Sixty two (62) copies of the questionnaire were retrieved and analyzed.

To generate the qualitative data, we adopted an in-depth personal interview through the use of open ended questions designed to clarify certain issues and obtain further intricate details about the phenomena under investigation which were difficult to capture through the structured questionnaire. Sometimes, since the interviews were conducted after the copies of the questionnaire with their responses have been retrieved; the interview was also used as a confirmatory test to check of some of the responses especially those that were not clear.

We observed the operations in the study units. Here, we adopted the socio-technical systems model (Susman and Evered, 1978). In this respect, the system's framework guided the collection of facts so that they were organized into an integrated whole about boundaries, transformation of inputs into outputs and the climate 
of the operations environment. Secondary data were generated from textbooks, journals, company bulletins, annual reports of firms and professional bodies. These materials were reviewed to obtain relevant information about the organisations and the phenomena we have studied.

\subsection{Research Hypotheses}

In undertaking this study, we were guided by the following hypotheses:

$\mathbf{H o}_{1}$ There is no significant relationship between production control and cost minimization in the Nigerian Manufacturing Industry.

$\mathrm{Ho}_{2}$ There is no significant relationship between production control and enhanced equity capital in the Nigerian Manufacturing Industry.

$\mathbf{H o}_{3}$ There is no significant relationship between production control and growth in the Nigerian Manufacturing Industry.

\section{Guide To Decision.}

This section provides a verification of the hypotheses that were stated earlier using the simple linear regression analysis.

$\mathrm{H}_{01}$ : There is no significant relationship between production control and cost minimization in the Nigerian manufacturing industry.

In testing this hypothesis, operational efficiency as the variable measure for cost minimization of the selected companies was regressed with the percentage responses of the influence of production control on productivity performance. The result obtained is presented in the table below;

Table 4.1: The Relationship between Production Control and Cost Minimization

\begin{tabular}{|l|c|}
\hline \multicolumn{1}{|c|}{ Statement Variables } & Values \\
\hline Co-efficient of correlation & 0.91 \\
\hline Co-efficient of determination & 0.828 \\
\hline $\mathrm{t}$-statistic & 4.076 \\
\hline p-value & 0.004 \\
\hline Intercept & 1.861 \\
\hline Partial Regression Co-efficient & 0.001 \\
\hline
\end{tabular}

\section{Source; SPSS Version 16 Window Output}

The table shows an R-value of 0.91 , which suggests a very strong relationship between production control and cost minimization. The co-efficient of determination shows that $82.8 \%$ variation in cost minimization is accounted for by changes in production control, hence the model is a good fit. Therefore, the null hypothesis was rejected.

$\mathrm{H}_{02}$ : There is no significant relationship between production control and equity capital in the Nigerian manufacturing industry.

In testing this hypothesis, equity capital of the selected companies was regressed with the percentage responses of the influence of production control on productivity performance. The result obtained is presented in the table below.

Table 4.3: The Relationship between Production Control and Equity Capital

\begin{tabular}{|l|c|}
\hline \multicolumn{1}{|c|}{ Statement Variables } & Values \\
\hline Co-efficient of correlation & 0.701 \\
\hline Co-efficient of determination & 0.49 \\
\hline t-statistic & 2.777 \\
\hline p-value & 0.000 \\
\hline Intercept & 6.30036 \\
\hline Partial Regression Co-efficient & 40516.012 \\
\hline
\end{tabular}

Source; SPSS Version 16 Window Output

The table shows an R-value of 0.701 , which suggests a strong relationship between production control and equity capital. The co-efficient of determination shows that $49 \%$ variation in equity capital was accounted for by variations in production control, hence the model is a moderate fit. Therefore, the null hypothesis was rejected.

$\mathrm{H}_{03}$ : There is no significant relationship between production control and growth in the Nigerian manufacturing industry.

In testing this hypothesis, net profit before tax as the variable measure for growth of the selected companies was 
regressed with the percentage responses of the influence of production control on productivity performance. The result obtained is presented in the table below;

Table 4.3: The Relationship between Production Control and Growth.

\begin{tabular}{|l|c|}
\hline \multicolumn{1}{|c|}{ Statement Variables } & Values \\
\hline Co-efficient of correlation & 0.78 \\
\hline Co-efficient of determination & 0.608 \\
\hline t-statistic & 3.605 \\
\hline p-value & 0.002 \\
\hline Intercept & 2.33236 \\
\hline Partial Regression Co-efficient & 15256.936 \\
\hline
\end{tabular}

\section{Source; SPSS Version 16 Window Output}

The table shows an R-value of 0.78 , which indicates a strong relationship between production control and growth. The co-efficient of determination shows that $60.8 \%$ variation in growth is accounted for by production control, hence the model is a good fit. Therefore, the null hypothesis was rejected.

The following findings were therefore drawn;

1) Control of production activities enhances operational efficiency of the firm.

2) Control of production activities enhances equity capital of the firm.

3) Control of production activities enhances growth of the firm.

\section{Discussion Of Findings}

The logical question one may ask at this point is "what do the research findings entail"? Therefore, this section of the study is focused on a brief discussion of the research findings by relating them one after the other to previous studies.

\subsection{Production Control and Productivity Performance}

With production control, a firm can meet customer requests for delivery times when feasible, meet the present goals for inventory levels, and minimize per unit cost of production. We observed in this study that production control is a veritable weapon for improved productivity performance in Nigerian manufacturing firms. It was gathered that $82.8 \%$ variation in operational efficiency, $49 \%$ variation in equity capital, and $60.8 \%$ variation in firm's growth was accounted for by controlling production operations. A brief analysis of these findings revealed that even in most organizations where there is no formal planning, effort are always made in controlling operations by ensuring that actual output conforms to expected output.

The outcome of this study aligns with previous studies reported by Ikan (2003) that production control aids managers in responding to the resulting threats and opportunities. It detects changes that affect the organization's products and services, thereby promoting corporate growth. Matsushita (2001), reported that customers' demand for improved design, quality or delivering time from shareholders and management wealth maximization are mere illusions without effective production control. Abrahamson and Pickle (1990), reported that value-added to a product or service so that customers will favour the firm's products as against competitors offer takes the form of above-average quality, which is usually achieved through control procedures.

\section{Recommendations}

Based on the findings of this study, the following recommendations were suggested;

1) Since production control enhances corporate productivity performance, Nigerian manufacturing firms must with seriousness be involved in efficient, effective and formal planning of production activity and its implementation, irrespective of the size and age of the firm.

2) Nigerian manufacturing firms should embrace the application of advanced manufacturing technology, such as automated production technology, computer assisted design and manufacturing (CAD/CAM), robotics and flexible, manufacturing systems.

3) To ensure effective application of advanced manufacturing technology in the Nigerian manufacturing industry, professionals with high technical knowhow should be hired by the organization and effective training programmes should be organized, especially in areas of lean manufacturing and just-in -time production concepts, for the organizational members who are to be affected by the technological advancement.

4) There should be a formal relationship between the Nigerian manufacturing sector and the tertiary institutions. This will go a long way to make research activities and findings efficient and effective. The relationship between town and gown should be encouraged. 


\section{References:}

[1] Abrahamson, F.A. and Pickle, G. (1990) "The Interface of Production and Marketing - An Empirical Analysis"; Journal of Industrial Marketing; 7 (1): 212-236.

[2] Agbadudu A.B. (1996) Elementary Operations Research 2, Benin: Mudiaga Press.

[3] Anwuluorah, M. C. (1987): "Surveys and when is a survey best in Social Research and Information Gathering" in Ugwuegbu, D.C.E. and Onwumere, S. O. (ed) Social Research and Information Gathering, (Lagos, F. G. Printers) p.17 - 27.

[4] Bestwick, P. P. and Lockyer, K. (2008) Quantitative Production Management, London: Pitman

[5] Billington, P. I.; McClain J. O. and Thomas, L. J. (2003) Mathematical Approaches to Capacity-Constrained MRP Systems: Review, Formulation and Problem Reduction, Management Science, Vol. 29, No. 10 (October), pp.1126-1141

[6] Brayton, G.N. (1983). "Simplified Method of Measuring Productivity Identifies Opportunities for Increasing It". Industrial Engineering. February

[7] Buffa, E.S. (2001) Production and Operations Management, New York: Krieger Publishing

[8] Chase, R. B; Aquilano, J.J; and Jacobs 1;. R. (2001) Operations Management for Competitive Advantage, Boston: McGraw-Hill.

[9] Chinweizu, C (1979) The West and The Rest of US, London: NOK Publishers

[10] Craig, C.; Harris, R. (1973). "Total Productivity Measurement at the Firm Level". Sloan Management Review (Spring 1973): 1328.

[11] Davis, H.S. (2005). Productivity Accounting. University of Pennsylvania.

[12] Eleanya, L. U. M. (2009) De-Industrialization and the Stability of Nation States, Port Harcourt: RIVCAS

[13] Eke, C. (1985) "Why Africa is not Developing West Africa", June, 17 pp $1212-1214$.

[14] Everette, E.A. (2006) Production and Operations Management - A New Approach; Englewood Cliffs; Prentice-Hall Inc.

[15] Fowge, F. P. (1997) Modernization without Development in Africa, Africa World Press INC. Asmara, Eritrea.

[16] Graves, Stephen C. (1999) Manufacturing Planning and Control, Massachusetts Institute of Technology, (November), pp. 17 - 25

[17] Green, R. (2006) The 33 Strategies of War, New York: Penguin Group

[18] Higgins, J.M. (2001) Strategic Management and Operations; Chicago; The Diyden Press

[19] Hillier Fredrick .S. and Lieberman Gerald I. (2005) Introduction to Operations Research, New York: McGraw Hill Inc.

[20] Ikan, N. (2003) "Impact of Production Control on Corporate Growth"; Decision Science; 27 (4); 616-639.

[21] Jain K. C.; and L, N. Aggarwal (2008) Production Planning, Control and Industrial Management, Delhi, Nai-Sarak: Khalma Publishers.

[22] Jaja, S.A. (2005)Small Business Paradigm; Port Harcourt, Pearl Publishers.

[23] Johnson L. A. and Montgomery, D. C. (2009) Operations Research in Production Planning, Scheduling and Inventory Control, New York: John Wiley.

[24] Jorgenson, D.V.; Griliches, Z. (1967). "The Explanation of Productivity Change". Review of Economic Studies 34 (99): $249-283$. doi:10.2307/2296675. JSTOR 2296675.

[25] Kendrick, J.; Creamer, D. (2005). Measuring Company Productivity: A handbook with Case Studies (89). The National Industry Productivity Board.

[26] Kendrick, J.W. (2004). Improving Company Productivity. The Johns Hopkins University Press.

[27] Lockyer, K. G. (2009) Factory and Production Management, London Pitman

[28] Matsushita, K. (2001) "Production Control and Customers' Satisfaction in Industrial Market"; Princeton University Journal of Management; 9 (1): 107-123.

[29] Mundel, M.E. (1983). Improving Productivity and Effectiveness. Prentice-Hall, Inc.

[30] Nachimias, C. and Nachimias, D. (1981); Research Methods in the Social Sciences, Alternative Second Edition without Statistics. Edward Anold (Publishers) Ltd. London.

[31] Nachimias, D. and Nachimias C. (1976): Research Methodology in the Social Science. UK'Edward Arnold.

[32] Olarewaju, A.D. (2010) "Productivity Improvement Techniques in the Public Service"; International Journal of Management and Administration; 31(1): 144-159

[33] Olusegun, D. and Adegbuyi, F.M. (2010) "The Effect of Production Planning and Organizational Productivity"; in Olusegun, D and Adegbuyi, F.M. (Ed.) Production Management - A Strategic Approach; Ibadan; Heinemann Publishers

[34] Pineda, A. (2009). A Multiple Case Study Research to Determine and respond to Management Information Need Using TotalFactor Productivity Measurement (TFPM). Virginia Polytechnic Institute and State University

[35] Poterba, D. (2006) "Work Schedule and Business Growth in India Manufacturing Firms"; Administrative Science Quarterly; 21(2): $247-261$.

[36] Susman G.I; and R. Evered R. (1978); “The Scientific Merits of Action Research”. Administrative Science Quarterly. Vol. 123 p 599.

[37] Thomas. L. J. and J. O. McClain, (2005) An Overview of Production Planning, In S. C. Graves, A. H. G. Rinnooy Kan and P. H. Zipkin (eds.) Handbooks in Operations Research and Management Science, Logistics of Production and Inventory, Vol.4, pp. 333370 ,

[38] Umoh G. I. (2005) Quantitative Analysis for Modeling and Decision Making, Nigeria: Lynno Company.

[39] Vollman, T. E., Berry, W. L. and Why Bark, D.C. (2007) Manufacturing Planning and Control Systems, Boston: McGraw-Hill.

[40] Weimer, A.M.(1999) Introduction to Business - A Management Approach; Homewood Illinois; Richard D. Irwin.

[41] Wild R. (2008) Production and Operations Management, New York: Holt, Risehart and Winston

[42] Winston, W. L. (2004) Operations Research: Applications and Algorithms, California: ITP Wadsworth Inc

[43] Winston, W. L. and Albright, S. C. (2007) Practical Management Science: Spread Sheet Modeling and Applications, California: ITP Wadsworth Inc.

G. I. Umoh is an Associate Professor in the University of Port Harcourt. He is presently the Head of Department of Management. He is a member of the Institute of Data Processing London. His areas of Specialization include Operational research applications in business, Advanced Statistics and Statistical analysis, Operations/Production Management, Human factors engineering otherwise known as Ergonomics, Management Information Systems. He is a Fellow, Nigerian Institute of Corporate Administration. He is a Member, Operational Research Society, UK, Member, Institute of Data Processing, London, Member, 
Ergonomics Society, UK, Member, Institute of Production Engineers, Uk. Member, The Academy of Management Nigeria.

NB: Dr Ify Harcourt Wokocha is a Chief Lecturer and Head, Department of Office Technology and Management in the School of Management Sciences, Rivers State College of Arts and Science, Rumuola Port Harcourt, Rivers State, Nigeria. He is a member of Nigerian Institute of Management (Chartered). He holds a B.Sc degree in Economics, MBA in Management, MBA in Banking and Finance and a Ph.D in Operations and Production Management. 